\title{
AUDIT REPORT LAG PADA PERUSAHAAN MANUFAKTUR DI BURSA EFEK INDONESIA
}

\author{
WIDYAWATI LEKOK \\ VERLIN RUSLY
}

\author{
Trisakti School of Management, Jl. Kyai Tapa No. 20, Grogol, Jakarta Barat, Indonesia \\ wlk@stietrisakti.ac.id
}

\begin{abstract}
This research examines the factors that influence audit report lag. The independent variables in this research are firm size, profitability, solvability, accounting firm size, age of company, audit committee size, independent board of commissioners, and ownership concentration. Audit report lag as the dependent variable in this research. The research population is manufacturing companies listed on the Indonesia Stock Exchange for the period of 2016-2018. There are 228 data that meet the sample criteria. The samples are collected using purposive sampling method. This research is analyzed using multiple regression analysis. The result identified that firm size, profitability, age of company had influence on audit report lag. While solvability, accounting firm size, audit committee size, independent board of commissioners, and ownership concentration had no influence on audit report lag.
\end{abstract}

Keywords: Audit report lag, firm size, profitability, age of company

\begin{abstract}
Abstrak: Penelitian ini menguji faktor-faktor yang mempengaruhi audit report lag. Variabel independen dalam penelitian ini adalah ukuran perusahaan, profitabilitas, solvabilitas, ukuran kantor akuntan publik, umur perusahaaan, ukuran komite audit, dewan komisaris independen, dan konsentrasi kepemilikan. Audit report lag digunakan sebagai variabel dependen dalam penelitian ini. Populasi penelitian ini mengunakan perusahaan manufaktur yang terdaftar di Bursa Efek Indonesia pada periode 2016-2018. Terdapat 228 data yang memenuhi kriteria sampel. Sampel dikumpulkan menggunakan metode purposive sampling. Penelitian ini dianalisis menggunakan metode regresi berganda. Hasil dari penelitian ini menunjukkan bahwa ukuran perusahaan, profitabilitas, dan umur perusahaan berpengaruh terhadap audit report lag, sedangkan variabel independen lainnya yaitu solvabilitas, ukuran kantor akuntan publik, ukuran komite audit, dewan komisaris independen, dan konsentrasi kepemilikan saham tidak berpengaruh terhadap audit report lag didalam perusahaan.
\end{abstract}

Kata kunci: $\quad$ Audit report lag, ukuran perusahaan, profitabilitas, umur perusahaan

\section{PENDAHULUAN}

Laporan keuangan tahunan pada dasarnya menjadi suatu dasar pertimbangan dalam pengambilan keputusan investasi dalam pasar modal. Perusahaan yang terdaftar di pasar modal diwajibkan untuk menyampaikan laporan keuangan yang sudah diaudit kepada publik (Firnanti 2016). Menurut lkatan Akuntan Indonesia (2009), laporan keuangan memiliki tujuan untuk menyediakan informasi yang berhubungan dengan posisi, kinerja, dan perubahan posisi atas laporan keuangan dalam suatu perusahaan yang bermanfaat bagi pengguna laporan keuangan dalam mengambil keputusan ekonomi. 
Berdasarkan PSAK pada Kerangka Dasar Penyusunan Penyajian Laporan Keuangan paragraf 43 (2012) menyatakan bahwa apabila terdapat penundaan yang tidak semestinya dalam pelaporan, maka informasi yang dihasilkan akan kehilangan relevansinya. Emiten atau Perusahaan Publik wajib untuk menyampaikan Laporan tahunan kepada Otoritas Jasa Keuangan paling lambat pada akhir bulan keempat setelah tahun buku perusahaan berakhir (Otoritas Jasa Keuangan 2016).

Pengenaan sanksi untuk keterlambatan penyampaian laporan keuangan juga diatur dalam Keputusan Direksi PT. Bursa Efek Jakarta Nomor 307/BEJ/07-2004 (2004) berupa peringatan tertulis I sampai III, dengan denda setinggi-tingginya Rp.500.000.000, sampai penghentian sementara perdagangan efek perusahaan tercatat (suspense) di bursa. Sanksi suspense perusahaan tercatat hanya akan dibuka apabila perusahaan tercatat telah menyerahkan laporan keuangan dan membayar denda sesuai ketentuan yang berlaku.

Penelitian ini bertujuan untuk menganalisis pengaruh ukuran perusahaan, profitabilitas, solvabilitas, ukuran kantor akuntan publik, umur perusahaan, ukuran komite audit, dewan komisaris independen, dan konsentrasi kepemilikan saham terhadap audit report lag pada perusahaan manufaktur di Bursa Efek Indonesia.

\section{Agency Theory}

Agency Theory yang dikemukakan oleh Jensen dan Meckling (1976), menjelaskan hubungan yang terjadi antara pihak agen (pihak manajemen) dengan principal (pemegang saham). Kepentingan antara pihak manajemen dan pemegang saham seringkali bertentangan dan dapat menyebabkan konflik diantara kedua pihak tersebut. Untuk menengahi kepentingan diantara keduanya maka perlu dilaksanakan suatu audit yang dilakukan oleh auditor independen.
Dalam teori agensi terdapat biaya berupa agency cost yaitu penjumlahan antara monitoring cost, bonding cost, dan residual loss. Adapula beberapa cara untuk mengurangi terjadinya agency cost, salah satunya adalah dengan kepemilikan saham perusahaan oleh pihak manajemen. Hal ini akan mengurangi potensi konflik yang ada antara pemegang saham (principal) dan manajemen (agent) sehingga manajemen akan termotivasi untuk meningkatkan kinerjanya dan lebih berhati-hati akan keputusan yang diambil karena pihak manajemen juga ikut menanggung resiko dari setiap keputusan (Lusiana and Wijoyo 2017). Konflik kepentingan diantara keduanya dapat diminimalkan dengan cara mensejajarkan kepentingan diantara kedua pihak yaitu pihak manajer dan pemegang saham dengan adanya kepemilikan manajerial (Imanta and Satwiko 2011).

\section{Audit Report Lag}

Menurut Mazkiyani dan Handoyo (2017), ketepatan waktu laporan keuangan yang telah diaudit memberikan kontribusi besar dalam pertimbangan proses pengambilan keputusan. Oleh karena itu, laporan keuangan yang telah diaudit harus dipublikasikan secara tepat waktu, karena ketersediaan dan juga keakuratan informasi keuangan diperlukan bagi pemegang saham, investor, dan pengguna lain sebagai pengambil keputusan. Jangka waktu penyelesaian audit laporan keuangan dapat diukur berdasarkan lamanya hari yang dibutuhkan untuk memperoleh laporan auditor independen, terhitung sejak tanggal tahun tutup buku perusahaan sampai tanggal yang tertera pada laporan auditor independen, dikenal dengan audit report lag.

Tujuan menyeluruh dari suatu audit laporan keuangan adalah menyatakan pendapat apakah laporan keuangan klien telah menyajikan secara wajar dalam semua hal yang material sesuai dengan prinsip akuntansi yang berlaku umum. Ketepatan waktu perusahaan 
dalam mempublikasikan laporan keuangan kepada masyarakat umum tergantung dari ketepatan waktu auditor dalam menyelesaikan pekerjaan auditnya (audit report lag). Pentingnya ketepatan waktu pelaporan keuangan diakui oleh berbagai pihak yang berkepentingan karena hal tersebut bukan hanya berpengaruh pada nilai dan kualitas laporan keuangan tersebut namun juga membawa reaksi yang negatif dari pasar (Lianto and Kusuma 2010).

\section{Ukuran Perusahaan dan Audit Report Lag} Menurut Sulastini (2007) dalam Dewi dan Keni (2013), ukuran perusahaan ditentukan berdasarkan pada total aset perusahaan, sehingga semakin besar ukuran perusahaan maka sumber informasi yang disediakan perusahaan akan semakin luas dan mudah diakses ke publik. Setiawan dan Nahumury (2014) mengatakan bahwa perusahaan yang memiliki total aset yang besar cenderung memiliki kontrol internal yang baik sehingga dapat memaksimalkan kesalahan dan mempercepat proses audit yang dilakukan oleh auditor independen dan dapat mengurangi tingkat terjadinya audit report lag.

$\mathrm{H}_{1}$ Ukuran perusahaan berpengaruh terhadap audit report lag

\section{Profitabilitas dan Audit Report Lag}

Mazkiyani dan Handoyo (2017), Lianto dan Kusuma (2010), serta Suparsada dan Putri (2017) berpendapat bahwa informasi kinerja keuangan terutama profitabilitas dapat menilai potensi perubahan sumber daya ekonomi yang akan digunakan di masa depan. Perusahaan yang memiliki tingkat profitabilitas yang lebih tinggi membutuhkan waktu dalam pengauditan laporan keuangan lebih cepat dikarenakan keharusan untuk menyampaikan kabar baik secepatnya kepada publik. Mereka juga memberikan alasan bahwa auditor yang menghadapi perusahaan yang mengalami kerugian memiliki respon yang cenderung lebih berhati-hati dalam melakukan proses pengauditan. Jika perusahaan menghasilkan tingkat profitabilitas yang lebih tinggi maka audit report lag akan lebih pendek dibandingkan perusahaan dengan tingkat profitabilitas yang lebih rendah.

$\mathrm{H}_{2}$ Profitabilitas berpengaruh terhadap audit report lag

\section{Solvabilitas dan Audit Report Lag}

Solvabilitas digunakan untuk menunjukkan kemampuan perusahaan dalam mengelola hutang-hutangnya baik itu hutang jangka panjang maupun hutang jangka pendek (Artaningrum, Budiartha, and Wirakusuma 2017). Risiko perusahaan yang memiliki solvabilitas yang tinggi dapat mengindikasikan bahwa suatu perusahaan sedang mengalami kesulitan keuangan dan dapat menunda pelaporan keuangannya kepada masyarakat karena hal tersebut bersifat bad news (Dewangga and Laksito 2015).

$\mathrm{H}_{3}$ Solvabilitas berpengaruh terhadap audit report lag

\section{Ukuran Kantor Akuntan Publik dan Audit Report Lag}

Kantor akuntan publik, yang selanjutnya disingkat KAP, adalah badan usaha yang didirikan berdasarkan ketentuan yang peraturan perundang-undangan dan mendapatkan izin usaha berdasarkan Undang-Undang ini (Undang-Undang RI No. 5 Tahun 2011 tentang Akuntan Publik 2011). Arens et al. (2014) menyatakan bahwa KAP bertanggung jawab untuk mengaudit laporan keuangan perusahaan yang sahamnya diperdagangkan secara publik. KAP Big Four adalah empat KAP terbesar di dunia, yaitu Deloitte \& Touche, Ernst \& Young, PricewaterhouseCoopers, dan KPMG (Arens, Elder, and Beasley 2014). Perusahaan biasanya menganggap bahwa KAP Big Four membutuhkan waktu yang lebih singkat untuk menyelesaikan audit dibandingkan dengan KAP Non Big Four, karena KAP Big Four dianggap lebih efsien dan memiliki tingkat fleksibilitas jadwal waktu yang lebih tinggi untuk 
menyelesaikan proses laporan audit secara tepat waktu (Sari and Ghozali 2014). KAP besar memperoleh insentif yang lebih tinggi untuk menyelesaikan pekerjaan auditnya lebih cepat dibandingkan dengan KAP lainnya. Waktu audit yang lebih cepat juga merupakan cara KAP besar untuk mempertahankan reputasi mereka (Iskandar and Trisnawati 2010).

$\mathrm{H}_{4}$ Ukuran kantor akuntan publik berpengaruh terhadap audit report lag

\section{Umur Perusahaan dan Audit Report Lag}

Mazkiyani dan Handoyo (2017), mengungkapkan bahwa perusahaan yang telah berumur memiliki banyak pengalaman dalam berbagai bidang masalah yang terkait dengan kesalahan-kesalahan yang terjadi dalam perusahaan dan bagaimana cara untuk mengatasinya, sehingga perusahaan cenderung memiliki tingkat fleksibilitas yang tinggi dalam menghadapi perubahan yang akan terjadi. Menurut Alsmady (2018), perusahaan yang lebih berumur sangat berkomitmen untuk menerbitkan laporan keuangan yang tepat waktu dan juga dalam pengungkapan hal-hal dalam laporan keuangan karena perusahaan yang sudah tua sangat memperhatikan citra mereka dipasar.

$\mathrm{H}_{5}$ Umur perusahaan berpengaruh terhadap audit report lag

\section{Ukuran Komite Audit dan Audit Report Lag}

Komite audit dibentuk oleh dan bertanggung jawab kepada Dewan Komisaris dalam membantu melaksanakan tugas dan fungsi Dewan Komisaris. Komite audit paling sedikit terdiri dari 3 (tiga) orang anggota yang berasal dari Komisaris Independen dan pihak dari luar emiten atau perusahaan publik (Otoritas Jasa Keuangan No. 55/POJK/04/2015 2015). Komite audit bertugas untuk memantau perencanaan dan pelaksanaan kemudian mengevaluasi hasil audit guna menilai kelayakan dan kemampuan dalam pengendalian intern untuk penyusunan laporan keuangan.
Semakin banyak jumlah komite audit maka audit delay akan semakin singkat karena penambahan ukuran komite audit cenderung meningkatkan proses pengawasan dalam penyusunan laporan keuangan yang sesuai dengan standar yang berlaku secara umum. Ini berarti waktu yang dibutuhkan auditor untuk melaksanakan audit menjadi lebih pendek (Janartha and Suprasto H. 2016).

$\mathrm{H}_{6}$ Ukuran komite audit berpengaruh terhadap audit report lag

\section{Dewan Komisaris Independen dan Audit Report Lag}

Setiawan dan Nahumury (2014) menyatakan bahwa semakin besar jumlah anggota dewan komisaris independent, semakin besar pula peningkatan kualitas pengawasan kepada dewan direksi yang dapat meminimalkan keterlambatan dalam laporan keuangan yang diaudit. Atmojo dan Darsono (2017) juga mengungkapkan bahwa dewan komisaris independen diharapkan mengurangi tindakan terjadinya kecurangan dalam penyajian laporan keuangan dikarenakan mereka tidak mempunyai hubungan dengan perusahaan terkait dan dapat melakukan pengawasan yang baik terhadap kegiatan manajemen. Dewan komisaris independen harus mengontrol jalannya proses audit dengan ketat sehingga audit report lag dapat diperpendek sehinga informasi laporan keuangan menjadi lebih berkualitas.

$\mathrm{H}_{7}$ Dewan komisaris independen berpengaruh terhadap audit report lag

\section{Konsentrasi Kepemilikan Saham dan Audit Report Lag}

$\begin{array}{ccc}\text { Menurut Atmojo dan Darsono } & \text { (2017), } \\ \text { konsentrasi } & \text { kepemilikan saham }\end{array}$ menggambarkan bagaimana dan siapa saja yang memegang kendali atas keseluruhan atau sebagian besar atas kepemilikan perusahaan serta keseluruhan atau sebagian besar pemegang kendali atas aktivitas bisnis pada 
suatu perusahaan tersebut. Butarbutar dan Hadiprajitno (2017) juga mengungkapkan bahwa konsentrasi kepemilikan saham adalah persentase jumlah dalam kepemilikan saham mayoritas di suatu perusahaan selain kepemilikan atas publik di dalam suatu struktur kepemilikan saham perusahaan. Semakin besar konsentrasi kepemilikan saham di dalam suatu perusahaan maka akan dapat mengurangi kebijakan manajemen perusahaan yang bersifat menyimpang. Hal ini dikarenakan mereka memiliki rasa kepemilikan yang besar juga (Halim 2018).

$\mathrm{H}_{8}$ Konsentrasi kepemilikan saham berpengaruh terhadap audit report lag

\section{METODA PENELITIAN}

Bentuk penelitian yang digunakan dalam penelitian ini adalah kausalitas. Populasi yang digunakan dalam penelitian ini adalah semua perusahaan manufaktur yang terdapat dalam Bursa Efek Indonesia pada periode tahun 2016-2018. Metode pengambilan sampel yang digunakan dalam penelitian ini adalah purposive sampling. Berikut beberapa kriteria yang digunakan dan hasil dari data atas kriteriakriteria tersebut:

Tabel 1 Prosedur Pemilihan Sampel

\begin{tabular}{lcc}
\hline \multicolumn{1}{c}{ Kriteria Sampel } & $\begin{array}{c}\text { Jumlah } \\
\text { Perusahaan }\end{array}$ & $\begin{array}{c}\text { Jumlah } \\
\text { Data }\end{array}$ \\
\hline $\begin{array}{l}\text { Seluruh perusahaan manufaktur yang konsisten terdaftar di Bursa } \\
\text { Efek Indonesia selama periode 2016-2018. }\end{array}$ & 178 & 534 \\
$\begin{array}{l}\text { Perusahaan yang tidak terdaftar di Bursa Efek Indonesia selama } \\
\text { periode 2016-2018. }\end{array}$ & $(35)$ & $(105)$ \\
$\begin{array}{l}\text { Perusahaan yang tidak menerbitkan laporan keuangan } \\
\text { menggunakan mata uang rupiah selama periode 2016-2018 }\end{array}$ & $(29)$ & $(87)$ \\
$\begin{array}{l}\text { Perusahaan yang menyajikan laporan keuangan tidak berakhir } \\
\text { pada periode per 31 Desember selama periode 2016-2018 }\end{array}$ & $(2)$ & $(6)$ \\
$\begin{array}{l}\text { Perusahaan yang laporan keuangannya tidak memperoleh laba } \\
\text { secara berturut-turut selama periode 2016-2018 }\end{array}$ & $(36)$ & $(108)$ \\
\hline Perusahaan yang dijadikan sampel & 76 & 228 \\
\hline Sumber: Hasil Pengumpulan Data & &
\end{tabular}

Audit report lag merupakan jangka waktu penyelesaian audit laporan keuangan yang diukur berdasarkan lamanya waktu hari yang dibutuhkan dalam proses audit hingga memperoleh laporan auditor independen, terhitung sejak tanggal akhir tahun tutup buku perusahaan (31 Desember) sampai tanggal opini audit yang tertera pada laporan keuangan auditor independen. Audit report lag (ARL) diukur menggunakan skala rasio, dengan rumus (Mutiara, Zakaria, and Anggraini 2018):
$A R L=$ Tanggal laporan keuangan - Tanggal laporan keuangan yang diaudit dan dikeluarkan

Nilai total aset diukur menggunakan log natural untuk menyederhanakan nilai miliaran dan bahkan triliunan yang terdapat dalam laporan keuangan, tanpa mengubah proporsi nilai dari nilai aktual. Aset yang diukur merupakan aset lancar dan aset tetap pada akhir periode (satu tahun) yang disebutkan dalam laporan keuangan yang diaudit 
(Mukhtaruddin et al. 2015). Pada penelitian ini, rumus yang digunakan untuk mengukur skala rasio ukuran perusahaan adalah dengan menggunakan rumus (Setiawan and Nahumury 2014):

$$
\text { SIZE }=\text { Ln (Total Aset) }
$$

Indikator skala rasio profitabilitas yang digunakan dalam penelitian ini adalah Return on Assets (ROA) dengan rumus (Mazkiyani and Handoyo 2017):

$$
\text { PL (ROA) }=\frac{\begin{array}{c}
\text { Laba Bersih } \\
\text { Setelah } \\
\text { Pajak }
\end{array}}{\text { Total Asset }}
$$

Solvabilitas tinggi mencerminkan tingkat risiko yang tinggi dalam keuangan perusahaan yang dianggap sebagai berita buruk dan menyebabkan pihak manajemen akan menunda laporan keuangan. Penelitian ini menggunakan pengukuran dengan skala rasio dan rumus sebagai berikut (Mutiara, Zakaria, and Anggraini 2018):

$$
\text { SOLVA }(\text { DAR })=\frac{\text { Total Liabilitas }}{\text { Total Asset }}
$$

Menurut penelitian yang dilakukan Mazkiyani dan Handoyo (2017) menyatakan bahwa yang termasuk dalam KAP Big Four, yaitu: Deloitte \& Touche, Ernst \& Young, PricewaterhouseCoopers, dan KPMG. Variabel dummy berskala nominal digunakan sebagai pengukuran dalam variabel ini (Mutiara, Zakaria, and Anggraini 2018), yaitu:

$\mathrm{KAP}=$

1, apabila perusahaan diaudit oleh KAP Big Four 0 , apabila perusahaan diaudit oleh KAP Non Big Four

Umur perusahaan diukur berdasarkan waktu terdaftarnya perusahaan atau listing date dipasar modal sampai tahun periode penelitian.
Umur perusahaan dapat diukur dengan skala rasio sebagai berikut (Mazkiyani and Handoyo 2017):

$$
\begin{gathered}
\text { AGE }=\text { Tahun Periode Penelitian } \\
- \text { Listing Date }
\end{gathered}
$$

Penelitian ini menggunakan pengukuran dengan skala rasio sebagai berikut (Setiawan and Nahumury 2014):

$$
\begin{gathered}
U K A=\text { Total Jumlah Anggota } \\
\text { Komite } \\
\text { Audit Pada Akhir Tahun }
\end{gathered}
$$

Variabel ini diukur dengan menghitung skala rasio perbandingan antara jumlah anggota dewan komisaris independen dengan jumlah keseluruhan anggota dewan komisaris perusahaan pada 31 Desember (Setiawan and Nahumury 2014) dengan rumus sebagai berikut:

$$
\text { BOC }=\frac{\begin{array}{c}
\text { Jumlah Anggota Dewan } \\
\text { Komisaris Independen }
\end{array}}{\begin{array}{c}
\text { Keseluruhan Anggota } \\
\text { Dewan Komisaris Perusahaan }
\end{array}}
$$

Variabel ini diukur dengan menghitung perbandingan proporsi jumlah saham yang dipegang oleh lima pemegang saham terbesar dengan jumlah total saham yang beredar didalam perusahaan. Penelitian kepemilikan saham terkonsentrasi diukur menggunakan skala rasio dengan rumus sebagai berikut (Setiawan and Nahumury 2014):

$$
\text { SOC }=\frac{\begin{array}{c}
\text { Saham Beredar Yang } \\
\text { Dimiliki Oleh Lima Pemegang } \\
\text { Saham Terbesar }
\end{array}}{\text { Total Nilai Saham Yang Beredar }}
$$

\section{HASIL PENELITIAN}

Berikut merupakan statistik deskriptif yang merupakan hasil pengujian dari hipotesis 
yang dilakukan yang dapat dilihat berdasarkan tabel 2 di bawah ini:

Tabel 2 Hasil Uji Statistik Deskriptif

\begin{tabular}{lcccc}
\hline Variabel & Minimum & Maximum & Mean & Std. Deviation \\
\hline ARL & 22,0000 & 157,0000 & 75,649123 & 16,1086523 \\
SIZE & 25,2156 & 33,4737 & 28,597462 & 1,5743472 \\
PL & 0,0003 & 0,9210 & 0,082351 & 0,0992933 \\
SOLVA & 0,0769 & 2,0558 & 0,424347 & 0,2508995 \\
KAP & 0 & 1 & 0,40 & 0,492 \\
AGE & 0,0000 & 37,0000 & 20,118421 & 9,4816778 \\
UKA & 1,0000 & 5,0000 & 3,096491 & 0,3975542 \\
BOC & 0,2000 & 0,8000 & 0,415993 & 0,1051223 \\
SOC & 0,2940 & 0,9943 & 0,735416 & 0,1546229 \\
\hline
\end{tabular}

\section{Sumber: Hasil Pengolahan Data SPSS 25}

Hasil uji multikolinearitas pada tabel 3 menunjukkan bahwa semua variabel memiliki nilai tolerance diatas 0,1 dan VIF dibawah 10 , maka dapat ditunjukkan bahwa data pada penelitian yang dilakukan tidak menunjukkan bahwa tidak terjadi multikolinearitas pada seluruh variabel independent (Ghozali 2018).
Hasil tersebut menyatakan bahwa data dapat digunakan dalam penelitian karena tidak terdapat hubungan antar variabel independen.

Berikut merupakan hasil pengujian dari uji multikolinearitas yang dilakukan yang dapat dilihat berdasarkan tabel dibawah ini:

Table 3 Hasil Uji Multikolinearitas

\begin{tabular}{|c|c|c|}
\hline \multirow[b]{2}{*}{ Variabel } & \multicolumn{2}{|c|}{ Collinearity Statistics } \\
\hline & Tolerance & VIF \\
\hline SIZE & 0,686 & 1,457 \\
\hline PL & 0,717 & 1,395 \\
\hline SOLVA & 0,827 & 1,209 \\
\hline KAP & 0,576 & 1,736 \\
\hline AGE & 0,851 & 1,176 \\
\hline UKA & 0,882 & 1,134 \\
\hline $\mathrm{BOC}$ & 0,787 & 1,271 \\
\hline SOC & 0,857 & 1,167 \\
\hline
\end{tabular}

Sumber: Hasil Pengolahan Data SPSS 25

Hasil uji heteroskedastisitas dapat dilihat pada tabel 4 yang menunjukkan bahwa variabel ukuran perusahaan dan umur perusahaan memiliki nilai sig. lebih kecil dari 0,05 , artinya terjadi heteroskedastisitas dimana terdapat kesamaan variasi dari error pada dua variabel tersebut. Variabel profitabilitas, solvabilitas, ukuran kantor akuntan publik, ukuran komite audit, dewan komisaris independen, dan konsentrasi kepemilikan saham memiliki nilai sig. lebih besar sama dengan dari 0,05 , yang artinya pada variabelvariabel tersebut menunjukkan tidak terjadi heteroskedastisitas pada penelitian yang dilakukan. Berikut merupakan hasil pengujian 
dari uji heteroskedastisitas yang dilakukan yang

dapat dilihat berdasarkan tabel dibawah ini:

\begin{tabular}{lc}
\multicolumn{2}{l}{ Tabel 4 Hasil Uji Heteroskedastisitas } \\
\hline \multicolumn{2}{l}{ Variabel } \\
\hline SIZE & Sig. \\
PL & 0,047 \\
SOLVA & 0,118 \\
KAP & 0,774 \\
AGE & 0,732 \\
UKA & 0,000 \\
BOC & 0,391 \\
SOC & 0,160 \\
\hline
\end{tabular}

Variabel dependen: Ares

Sumber: Hasil Pengolahan Data SPSS 25

Hasil uji autokorelasi dengan menggunakan uji breusch-godfrey (uji BG) yang dapat dilihat pada tabel 5 menunjukkan nilai sig. sebesar 0,424 dan nilai tersebut lebih besar sama dengan dari 0,05 , yang dapat disimpulkan bahwa tidak terdapat masalah autokorelasi dalam data penelitian. Berikut merupakan tabel dari hasil pengujian dari uji autokorelasi yang dilakukan:

Tabel 5 Hasil Uji Autokorelasi

\begin{tabular}{lcc}
\hline & Sig. & Keterangan \\
\hline RES_2 & 0,424 & Tidak terjadi autokorelasi \\
\hline
\end{tabular}

Variabel dependen: Res_1

Sumber: Hasil Pengolahan Data SPSS 25

Pada tabel 6 dapat dilihat nilai koefisien korelasi $(R)$ sebesar 0,361 . Nilai $R$ lebih kecil dari 0,5 menunjukkan adanya hubungan yang rendah antara variabel dependen Audit Report Lag (ARL) dengan variabel independen ukuran perusahaan (SIZE), profitabilitas ( $P L)$, solvabilitas (SOLVA), ukuran kantor akuntan publik (KAP), umur perusahaan (AGE), ukuran komite audit (UKA), dewan komisaris independen (BOC), dan konsentrasi kepemilikan saham (SOC).

Nilai adjusted $\mathrm{R}^{2}$ sebesar 0,098 berarti variasi variabel dependen audit report lag (ARL) dapat dijelaskan oleh variasi variabel independen ukuran perusahaan (SIZE), profitabilitas (PL), solvabilitas (SOLVA), ukuran kantor akuntan publik (KAP), umur perusahaan (AGE), ukuran komite audit (UKA), dewan komisaris independen (BOC), dan konsentrasi kepemilikan saham (SOC) sebesar 9.8\%, sedangkan $90.2 \%$ dapat dijelaskan oleh variabel-variabel lain yang tidak dimasukkan ke dalam model penelitian ini. Berikut merupakan hasil pengujian dari Analisa koefisien korelasi dan determinasi yang dilakukan yang dapat dilihat berdasarkan table 6 di bawah ini: 
Tabel 6 Hasil Koefisien Korelasi dan Determinasi

\begin{tabular}{ccr}
\hline Model & $\mathbf{R}$ & Adjusted R Square \\
\hline 1 & $0,361^{\mathrm{a}}$ & 0,098 \\
\hline
\end{tabular}

Sumber: Hasil Pengolahan Data SPSS 25

Tabel 7 menunjukkan hasil sig. 0,000. Nilai sig. lebih kecil dari nilai 0,05 artinya model fit. Hal ini menunjukkan bahwa model layak digunakan ke dalam model penelitian. Berikut merupakan hasil pengujian dari uji $F$ yang dilakukan yang dapat dilihat berdasarkan tabel 7 di bawah ini:

Tabel 7 Hasil Uji F

\begin{tabular}{lcr}
\hline Model & $\mathbf{F}$ & Sig. \\
\hline Regression & 4,098 & $0,000^{\mathrm{b}}$ \\
\hline Sumber: Hasil & Pengolahan Data SPSS 25
\end{tabular}

Berikut merupakan hasil pengujian dari uji t yang dilakukan yang dapat dilihat berdasarkan tabel 8 di bawah ini. Model regresi yang dapat digambarkan adalah sebagai berikut:
Audit Report Lag (ARL) $=137,782-2,089$ SIZE - 31,597 PL + 1,600 SOLVA - 1,053 KAP + 0,388 AGE - 0,439 UKA + 8,190 BOC - 13,453 $\mathrm{SOC}+\varepsilon$

Tabel 8 Hasil Uji t

\begin{tabular}{lcc}
\hline \multicolumn{1}{c}{ Variabel } & B & Sig. \\
\hline (Constant) & 137,782 & 5,640 \\
SIZE & $-2,089$ & 0,008 \\
PL & $-31,597$ & 0,010 \\
SOLVA & 1,600 & 0,720 \\
KAP & $-1,053$ & 0,699 \\
AGE & 0,388 & 0,001 \\
UKA & $-0,439$ & 0,872 \\
BOC & 8,190 & 0,453 \\
SOC & $-13,453$ & 0,059 \\
\hline
\end{tabular}

Variabel dependen: ARL

Sumber: Hasil Pengolahan Data SPSS 25

Hasil uji t pada tabel 8 menunjukkan bahwa dilihat bahwa nilai signifikan variabel ukuran perusahaan (SIZE) sebesar 0,008 yang mana lebih kecil dibandingkan dengan alpha (a $=0,05$ ) yang menunjukkan bahwa $\mathrm{Ha}_{1}$ diterima. Hal ini dapat disimpulkan bahwa variabel ukuran perusahaan berpengaruh negatif terhadap audit report lag (ARL). Ukuran perusahaan memiliki pengaruh terhadap audit report lag, dikarenakan semakin besar ukuran perusahaan maka semakin tinggi tekanan yang dihadapi baik pihak manajemen dan auditor agar dapat melaporkan laporan keuangannya tepat waktu kepada publik sehingga dapat menghindari terjadinya keterlambatan penyampaian laporan keuangan (Mutiara, Zakaria, and Anggraini 2018). Perusahaan yang besar cenderung memiliki lebih banyak sumber daya manusia, perangkat organisasi yang lebih luas, serta teknologi informasi yang berkualitas sehingga sistem 
pengendalian internal perusahaan menjadi baik. Hal ini menunjang penyajian dan pengelolaan informasi akuntansi yang baik. KAP yang mengaudit laporan keuangan nampaknya dapat terbantu dengan kondisi demikian sehingga penyelesaian audit juga membutuhkan waktu yang lebih pendek ((Sari and Ghozali 2014) dan (Janartha and Suprasto H. 2016).

Pada tabel 8 , hasil uji t menunjukkan bahwa nilai signifikan variabel profitabilitas (PL) sebesar 0,010 yang mana hasil tersebut lebih kecil daripada alpha $(a=0,05)$. Hal tersebut dapat disimpulkan bahwa $\mathrm{Ha}_{2}$ diterima yang berarti profitabilitas $(\mathrm{PL})$ berpengaruh terhadap audit report lag. Hasil penelitian menunjukkan bahwa profitabilitas berpengaruh negatif terhadap audit report lag. Semakin tinggi pendapatan yang dimiliki oleh perusahaan, audit lag akan semakin pendek. Keterlambatan dalam penyampaian laporan keuangan semakin pendek karena perusahaan ingin segera menyampaikan kabar baik tersebut kepada para investor (pemegang saham) sehingga menarik investor untuk membeli saham perusahaan mereka ((Mazkiyani and Handoyo 2017), (Yendrawati and Mahendra 2018) dan (Mutiara, Zakaria, and Anggraini 2018)).

Pada hasil uji $t$ di atas menunjukkan bahwa nilai signifikan variabel solvabilitas (SOLVA) sebesar 0,720 yang mana nilainya lebih besar sama dengan dibandingkan dengan alpha $(a=0,05)$ sehingga disimpulkan bahwa $\mathrm{Ha}_{3}$ tidak diterima yang artinya variabel solvabilitas tidak berpengaruh terhadap audit report lag.

Pada tabel hasil uji t di atas, dapat dilihat bahwa nilai signifikan pada variable independen ukuran kantor akuntan publik (KAP) memiliki nilai signifikan sebesar 0,699. Nilai tersebut lebih besar sama dengan alpha $(\alpha=0,05)$ sehingga $\mathrm{Ha}_{4}$ tidak diterima. Hal ini menunjukkan bahwa ukuran kantor akuntan publik tidak berpengaruh terhadap audit report lag.

Pada tabel 8 , hasil uji t menunjukkan nilai signifikan pada variabel umur perusahaan
(AGE) sebesar 0,001 di mana nilai tersebut lebih kecil dari alpha $(\alpha=0,05)$. Hal tersebut dapat disimpulkan bahwa $\mathrm{Ha}_{5}$ diterima yang berarti umur perusahaan (AGE) berpengaruh terhadap audit report lag. Berdasarkan nilai B yaitu 0,388 , terdapat hubungan yang positif antara umur perusahaan dengan audit report lag. Umur perusahaan yang lebih besar memiliki tingkat kompleksitas yang tinggi karena perusahaan yang telah berdiri lama telah memiliki banyak cabang dan usaha baru, baik di dalam maupun di luar negeri, sehingga akan memperpanjang tingkat terjadinya audit report lag ((Widhiasari and Budiartha 2016) dan (Sitorus and Ardiati 2014)).

Hasil uji t di atas menunjukkan bahwa nilai signifikan pada variabel ukuran komite audit (UKA) memiliki nilai sebesar 0,872 dan nilai tersebut lebih besar sama dengan dibandingkan alpha $(\alpha=0,05)$. Hal tersebut dapat disimpulkan bahwa $\mathrm{Ha}_{6}$ tidak diterima yang artinya variabel ukuran komite audit (UKA) tidak berpengaruh terhadap audit report lag.

Hasil uji $t$ di atas menunjukkan bahwa nilai signifikan pada variabel dewan komisaris independen (BOC) sebesar 0,453 dan nilai tersebut lebih besar sama dengan alpha $(\alpha=$ $0,05)$. Hal tersebut dapat disimpulkan bahwa $\mathrm{Ha}$ tidak diterima yang berarti variabel dewan komisaris independen (BOC) tidak berpengaruh terhadap audit report lag.

Hasil uji $t$ di atas menunjukkan bahwa nilai signifikan pada variabel konsentrasi kepemilikan saham (SOC) sebesar 0,059 dan nilai tersebut lebih besar sama dengan dibandingkan alpha $(\alpha=0,05)$. Hal tersebut dapat disimpulkan bahwa Has tidak diterima yang berarti variabel konsentrasi kepemilikan saham (SOC) tidak berpengaruh terhadap audit report lag.

\section{PENUTUP}

Berdasarkan analisis dan pembahasan yang dilakukan terhadap 76 sampel perusahaan 
dan jumlah data sebanyak 228 data selama tahun 2016 sampai dengan tahun 2018 dapat diperoleh kesimpulan bahwa ukuran perusahaan dan profitabilitas berpengaruh negatif terhadap audit report lag, sedangkan umur perusahaan berpengaruh positif terhadap audit report lag. Solvabilitas, ukuran kantor akuntan publik, ukuran komite audit, dewan komisaris independen, dan konsentrasi kepemilikan saham tidak berpengaruh terhadap audit report lag.

Penelitian ini memiliki beberapa keterbatasan. Pertama, terdapat pengaruh lain di luar model regresi yang menyebabkan nilai adjusted $R^{2}$ hanya sebesar $9,8 \%$. Kedua, struktur kepemilikan saham hanya berfokus pada jumlah saham mayoritas dan jumlah saham publik, namun tidak terfokus pada struktur kepemilikan saham lainnya, seperti kepemilikan manajerial atau kepemilikan institusional. Ketiga, objek penelitian yang digunakan hanya terbatas pada perusahaan manufaktur yang terdapat pada Bursa Efek Indonesia dan kurang mewakili perusahaanperusahaan yang terdaftar lainnya di Bursa Efek Indonesia. Keempat, data residual dari hasil uji normalitas tidak berdistribusi normal walaupun sudah dilakukan uji outlier dan terdapat beberapa variabel independen dalam penelitian ini yang tidak memenuhi salah satu uji asumsi klasik yaitu uji heteroskedastisitas, yaitu variabel ukuran perusahaan (SIZE) dan umur perusahaan (AGE).Kelima, periode penelitian hanya dilakukan selama 3 tahun yaitu 20162018, sehingga hanya terdapat 76 sampel perusahaan (228 data) yang dapat digunakan sebagai data penelitian dari 178 jumlah populasi.

Saran yang dapat diberikan bagi penelitian selanjutnya adalah dengan menambahkan variabel independen lainnya yang diharapkan berpengaruh terhadap audit report lag, seperti opini audit, board meeting, dan untuk struktur kepemilikan saham difokuskan pada kepemilikan manajerial dan kepemilikan institusional. Untuk mengatasi data yang tidak berdistribusi normal disarankan dengan cara penambahan data, sedangkan masalah heteroskedastisitas disarankan dengan melakukan transformasi data. Perluasan objek penelitian yang dijadikan sampel untuk perusahaan yang diteliti juga disarankan, misalnya dengan menambah penelitian pada perusahaan non keuangan dan memperpanjang tahun pengamatan penelitian.

\section{REFERENCES:}

Alsmady, Ahnaf Ali. 2018. "The Effect of Board of Directors' Characteristics and Ownership Type on the Timeliness of Financial Reports." International Journal of Business and Management 13 (6): 276. https://doi.org/10.5539/ijbm.v13n6p276.

Arens, Alvin A, Randal J Elder, and Mark S Beasley. 2014. Auditing and Assurance Services: An Integrated Approach. Fifteenth. Singapore: Pearson.

Artaningrum, Rai Gina, I Ketut Budiartha, and Made Gede Wirakusuma. 2017. "Pengaruh Profitabilitas, Solvabilitas, Likuiditas, Ukuran Perusahaan Dan Pergantian Manajemen Pada Audit Report Lag Perusahaan Perbankan." E-Jurnal Ekonomi Dan Bisnis Universitas Udayana 6 (3): 1079-1108. https://ojs.unud.ac.id/index.php/EEB/article/view/24231.

Atmojo, Danang Tri, and Darsono. 2017. "Analisis Faktor-Faktor Yang Berpengaruh Terhadap Audit Report Lag (Studi Empiris Pada Perusahaan Yang Terdaftar Di Bursa Efek Indonesia Tahun 2013-2015)." Diponegoro Journal of Accounting 6 (4): 1-15.

Butarbutar, Rizki Sakti Kornelius, and P Basuki Hadiprajitno. 2017. "Analisis Faktor-Faktor Yang Berpengaruh Terhadap Audit Report Lag ( Studi Empiris Pada Perusahaan Manufaktur Yang Terdaftar Di Bursa Efek Indonesia Tahun 2012-2015)" 6 (3): 1-12. http://ejournal-s1.undip.ac.id/index.php/accounting. 
Dewangga, Arga, and Herry Laksito. 2015. "FAKTOR-FAKTOR YANG BERPENGARUH TERHADAP AUDIT REPORT LAG." Diponegoro Journal of Accounting 4 (3): 1-8. https://doi.org/10.21067/mbr.v4i1.4768.

Dewi, Sofia Prima, and Keni. 2013. "Pengaruh Umur Perusahaan, Profitabilitas, Ukuran Perusahaan Dan Leverage Terhadap Pengungkapan Tanggung Jawab Sosial Perusahaan." Jurnal Bisnis Dan Akuntansi 15 (1): 112. https://doi.org/https://doi.org/10.34208/jba.v15i1.

Firnanti, Friska. 2016. "Faktor-Faktor Yang Mempengaruhi Audit Report Lag." Jurnal Bisnis Dan Akuntansi 18 (2): 167-75. http://www.tsm.ac.id/JBA.

Ghozali, Imam. 2018. "Aplikasi Analisis Multivariate Dengan Program IBM SPSS 25." In Aplikasi Analisis Multivariate Dengan Program IBM SPSS 25, 9th ed. Semarang: Badan Penerbit Universitas Diponegoro.

Halim, Yansen Cristian. 2018. "Faktor-Faktor Yang Mempengaruhi Audit Report Lag Periode 2013-2016 Di Bursa Efek Indonesia." Jurnal Muara IImu Ekonomi Dan Bisnis 2 (1): 54. https://doi.org/10.24912/jmieb.v2i1.1655.

Ikatan Akuntan Indonesia. 2009. Entitas Tanpa Akuntabilitas Publik. Standar Akuntansi Keuangan, Salemba Empat: Jakarta.

_. 2012. Kerangka Dasar Penyusunan Penyajian Laporan Keuangan. Standar Akuntansi Keuangan, Salemba Empat: Jakarta.

Imanta, Dea, and Rutji Satwiko. 2011. "Faktor-Faktor Yang Mempengaruhi Kepemilikan Managerial." Jurnal Bisnis Dan Akuntansi 13 (1): 67-80. https://doi.org/https://doi.org/10.34208/jba.v13i1.

Iskandar, Meylisa Januar, and Estralita Trisnawati. 2010. "Faktor-Faktor Yang Mempengaruhi Audit Report Lag Pada Perusahaan Yang Terdaftar Di Bursa Efek Indonesia." Jurnal Bisnis Dan Akuntansi 12 (3): 175-86.

Janartha, I Wayan Pion, and Bambang Suprasto H. 2016. "Pengaruh Ukuran Perusahaan, Keberadaan Komite Audit Dan Leverage Terhadap Audit Delay" 16.3: 2374-2407. https://ojs.unud.ac.id/index.php/Akuntansi/article/view/21497.

Jensen, Michael C., and William H. Meckling. 1976. "THEORY OF THE FIRM: MANAGERIAL BEHAVIOR, AGENCY COSTS AND OWNERSHIP STRUCTURE." Human Relations 3 (4): 305-60. https://doi.org/https://doi.org/10.1016/0304-405X(76)90026-X.

Lianto, Novice, and Budi Hartono Kusuma. 2010. "Faktor-Faktor Yang Berpengaruh Terhadap Audit Report Lag." Jurnal Bisnis Dan Akuntansi 12 (2): 98-107. https://doi.org/https://doi.org/10.34208/jba.v12i2.

Lusiana, Ester, and Dewi Sari Wijoyo. 2017. "Faktor-Faktor Yang Mempengaruhi Kebijakan Dividen Perusahaan Publik Non Keuangan." Jurnal Bisnis Dan Akuntansi 19 (1a-4): 281-91. https://doi.org/https://doi.org/10.34208/jba.v19i1a-4.

Mazkiyani, Nur, and Sigit Handoyo. 2017. "Audit Report Lag of Listed Companies in Indonesia Stock Exchange." Jurnal Aplikasi Bisnis 17 (1): 77-95. https://doi.org/10.20885/jabis.vol17.iss1.art5.

Mukhtaruddin, Ririn Oktarina, Relasari, and Abukosim. 2015. "Firm and Auditor Characteristics, and Audit Report Lag in Manufacturing Companies Listed on Indonesia Stock Exchange during 2008-2012." Expert Journal of Business and Management 3 (1): 13-26. http://business.expertjournals.com/wp-content/uplo ... ukhtaruddin13-26.pdf.

Mutiara, Yosia Taruli, Adam Zakaria, and Ratna Anggraini. 2018. "The Influence of Company Size, Company Profit, Solvency and CPA Firm Size on Audit Report Lag." Pressacademia 5 (1): 1-10. https://doi.org/10.17261/pressacademia.2018.779.

Otoritas Jasa Keuangan. 2016. "Otoritas Jasa Keuangan Nomor 29/POJK.04/2016." Indonesia.

Otoritas Jasa Keuangan No. 55/POJK/04/2015. 2015. "Otoritas Jasa Keuangan Republik Indonesia No. 55/Pojk/04/2015."

PT Bursa Efek Jakarta. 2004. "Keputusan Direksi PT Bursa Efek Jakarta Nomor: Kep-307/BEJ/07-2004 Tentang Peraturan Nomor 1-H Tentang Sanksi."

Sari, Revani Ratna, and Imam Ghozali. 2014. "FAKTOR - FAKTOR PENGARUH AUDIT REPORT LAG (Kajian Empiris Pada Perusahaan Manufaktur Yang Terdaftar Di Bursa Efek IndonesiaTahun 2010-2012)." Diponegoro Journal of Accounting 3 (2): 960-68. http://ejournal-s1.undip.ac.id/index.php/accounting.

Setiawan, Ganang, and Joicenda Nahumury. 2014. "The Effect of Board of Commissioners, Audit Committee, and Stock Ownership Concentration on Audit Report Lag of Banking Companies in Indonesia Stock 
Exchange." The Indonesian Accounting Review 4 (1): 15-28. https://doi.org/10.14414/tiar.14.040102.

Sitorus, Novita Jayanti, and Aloysia Yanti Ardiati. 2014. "Pengaruh Standar Akuntansi Keuangan Indonesia Baru, Ukuran Kantor Akuntan Publik, Ukuran Perusahaan Dan Umur Perusahaan Terhadap Audit Report Lag." MODUS 29 (2): 139-56.

Suparsada, Ni Putu Yulianda, and IGAM Asri Dwija Putri. 2017. "PENGARUH PROFITABILITAS, REPUTASI AUDITOR, UKURAN PERUSAHAAN, DAN KEPEMILIKAN INSTITUSIONAL TERHADAP AUDIT DELAY PADA PERUSAHAAN MANUFAKTUR." E-Jurnal Akuntansi Universitas Udayana 18 (1): 60-87. https://ojs.unud.ac.id/index.php/Akuntansi/article/view/20800.

Undang-Undang RI No. 5 Tahun 2011 tentang Akuntan Publik. 2011. "Undang-Undang RI No. 5 Tahun 2011 Tentang Akuntan Publik."

Widhiasari, Ni Made Shinta, and I Ketut Budiartha. 2016. "Pengaruh Umur Perusahaan, Ukuran Perusahaan, Reputasi Auditor, Dan Pergantian Auditor Terhadap Audit Report Lag." E-Jurnal Akuntansi Universitas Udayana 15 (1): 200-227.

Yendrawati, Reni, and Varaby Wahyu Mahendra. 2018. "The Influence of Profitability, Solvability, Liquidity, Company Size and Size of Public Accountant Firm on Audit Report Lag." The International Journal of Social Sciences and Humanities Invention 5 (12): 5170-78. https://doi.org/10.18535/ijsshi/v5i12.13. 
